\title{
Assessing fungicides for seedling protection of cucumber to collar rot disease caused by Sclerotium rolfsii
}

\author{
Ritesh Kumar ${ }^{1}$, Abhijeet Ghatak* and Arun P. Bhagat
}

Department of Plant Pathology, Bihar Agricultural University, Sabour (Bihar) India

${ }^{1}$ Department of Plant Pathology, Bidhan Chandra Krishi Viswavidyalaya, Mohanpur, Nadia (W.B.) India

\section{ARITCLE INFO}

Received : 31.01 .2018

Revised : 02.03 .2018

Accepted : 10.03 .2018

\section{KEY WORDS :}

Collar rot, Cucumber, Fungicide, Sclerotium rolfsii, Seedling protection

*Corresponding author:

ghatak11@gmail.com

\begin{abstract}
Sclerotium rolfsii Sacc. is known to be a serious pathogen on many crops of economic importance including cucurbits. Due to proliferic growth and ability to forming sclerotia, this pathogen is the major constraint in successful cultivation of cucumber. The present investigation was thus carried out to evaluate the potential of nine different fungicides i.e. carbendazim, thiophenate methyl, vinclozoline, captan, copper oxychloride, mancozeb, hexaconazole, mycobutanil and propiconazole at different concentrations of 10,50,100 and $150 \mathrm{ppm}$, on the growth inhibition of $S$. rolfsii. The primary assessment was made on in vitro screening of fungicides and its concentration whereby hexaconazole at lowest concentration $(10 \mathrm{ppm})$ rendered the most vital effect $(\mathrm{P} \leq 0.0001)$ on growth reduction ability followed by propiconazole and mycobutanil. No growth of S. rolfsii observed on plates amended with hexaconazole when the concentration was further increased. Similar effect was traced in an experiment conducted on root trainer. The percent infected plant also provided the same impact of fungicides received in toxic-assay experiment. Maximum seedlings protection of cucumber was achieved through seed application of hexaconazole even at lowest concentration $(\mathrm{P} \leq 0.01)$; similarly, no mortality was detected on higher concentration of this fungicide. Although our result directly claiming the best effect of hexaconazole but we propose to use a combination of fungicides from different groups in order to avoid resistance development in $S$. rolfsii against a particular fungicide. A combination of carbendazim and hexaconazole is hereby proposed for seedling protection of cucumber to S. rolfsii.
\end{abstract}

How to view point the article : Kumar, Ritesh, Ghatak, Abhijeet and Bhagat, Arun P. (2018). Assessing fungicides for seedling protection of cucumber to collar rot disease caused by Sclerotium rolfsii. Internat. J. Plant Protec., 11(1) : 10-17, DOI : 10.15740/HAS/IJPP/11.1/10-17. 